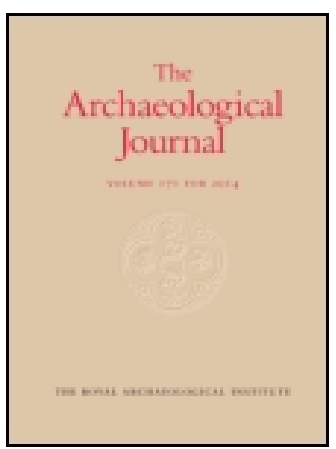

Archaeological Journal

\title{
On the Difficulties Connected with the Fourteenth Iter of Antonine
}

\author{
John Fitchett Marsh
}

To cite this article: John Fitchett Marsh (1878) On the Difficulties Connected with the Fourteenth Iter of Antonine, Archaeological Journal, 35:1, 54-62, DOI: 10.1080/00665983.1878.10851818

To link to this article: http://dx.doi.org/10.1080/00665983.1878.10851818

里 Published online: 14 Jul 2014.

Submit your article to this journal $₫$

Q View related articles $₫$ 


\section{ON THE DIFFIOUISTES CONNECTED WITH THE FOURTEENTH ITER OF ANTONINE.}

By JOHN FITCHETT MARSH.

It requires some little assurance to ask for a hearing for one more theory on the long vexed subject of the 14th Iter of Antonine. My best apology for doing so is that what I have to say is new, and I think not unimportant, and I will endeavour to make it short. At all events if there are already twenty different theories, at which number they are estimated by the late $\mathrm{Mr}$. Ormerod, in a paper on the subject, in the Bristol volume of the Transactions of the Archæological Institute, reprinted in his Striqulensia, I must have nineteen of them to keep me in countenance if I am wrong.

I do not intend to discuss-scarcely even to touch upon-the many questions which are involved in the controversy, such as the point at which the route of Antonine crosses the Estuary of the Severn, the route by which the ferry is reached from Aquæ Solis, or Bath, and the identification of the various places named in the Itinerary, though I hope the suggestion I am about to make will be found to throw light on all these points. Neither is it my intention to discuss the authority of Richard of Cirencester, nor have I any controversy with those who seek to identify the places named in his Itinerary. If they think they can find their way with him from Bath, by way of Sea-Mills, to a point below the mouth of the Wye, I have only to wish them a pleasant journey, regretting that my engagement on another route, under the guidance of Antonine, will prevent me from accompanying them. I would not be understood to hint a doubt of the existence of an important Roman station at Sea-Mills, or to deny that there was available, and was actually used under favourable circumstances of wind and tide, a passage thence by water to Sudbrook, on the 


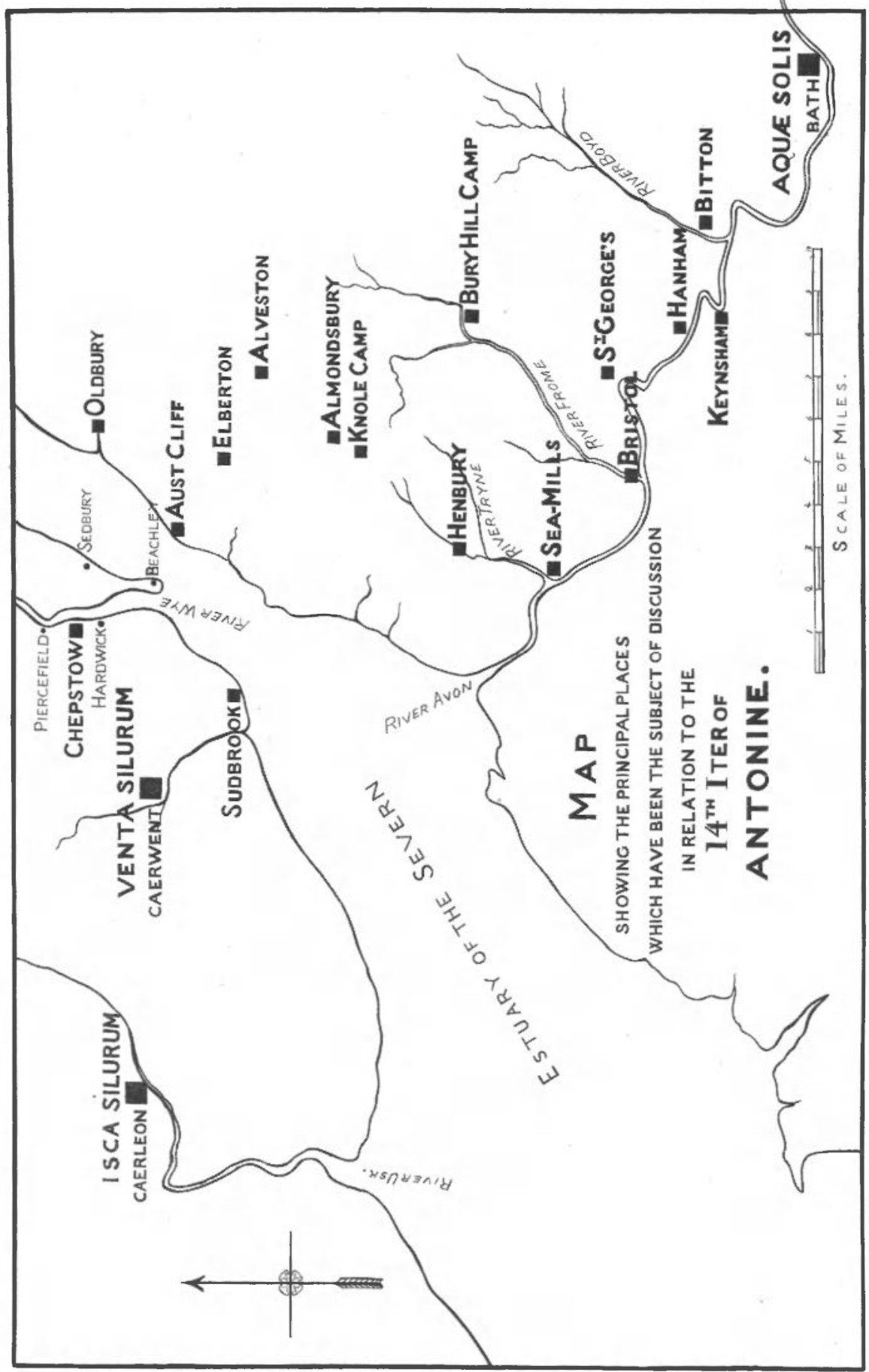


opposite side of the Estuary of the Severn, so as to join the Via Julia, on the westward route to Venta Silurum (Caerwent). If we are not to read a doubtful passage of Tacitus (xii, 31) as indicating that the Proprætor Ostorius Scapula established camps on the Avon and Severn,' we do not need that or any other express authority for the fact that at some period, before the subjugation of the Silures added Britannia Secunda to the Roman Empire, there must have been a chain of military stations, forming the defence of Roman Britain against the yet unconquered tribes beyond the Severn, and that these posts must have been connected by a road in the direction from near Sea-Mills towards Gloucester, a road which the geological features of the country would have been sufficient to identify with the lines marked on the Ordnance map as Cribbs Causeway and the Ridgeway, and which other evidence shews to have been marked by the stations of Henbury, Almondsbury, Alveston, \&c. 'These posts must also have been connected with $\Lambda$ quæ Solis; but the line of communication, when first established, had no reference to any route to the country of the Silures, and we should not, a priori, expect it to have any connexion with the Iter of Antonine now under discussion. The question is, how his Iter is to be interpreted-not how it is to be identified with the routes described by other writers, ancient or modern.

The well known difficulty, or rather element of uncertainty, in this part of his Itinerary (for it may be regarded

1 See a Paper by the Rer. Preben. dary Scarth, on the date of the foundation of Urioconium, \&c., in the 21st volume of the Archeological Journal, advocating the theory that Antona is to be there read Aufona, meaning the Nen. There is another position in that paper, to which I am unable to assent, namely that the Second Legion was stationed at Caerleon-on-Usk as early as the commencement of the war with the Silures, A.D. 50. It would require strong evidence to establish this fact, and, in the absence of any that I can detect, I should rather be inclined to say, with great deference to the author of the paper, that the existence of a permanent camp at Caerleon at any given period (for it is not a question of dates, but of the sequence of events) would in itself be evidence that the country of the Silures was already in the military occupation of the Romans. The fact of Ostorius marching against Caractacus from the north shews that a base of operations by land was preferred to one across the British Channel, while the strategy of Caractacus in transferring the seat of war to the country of the $O_{i}$ ? rices shews that he could not have had the enemy in his rear at Caerleon. The question is only so far material to the object of this paper as it bears upon my argument that the original establishment of a communication between Aqure Solis and the posts on the bank of the Severn had no reference to the means of access to the country of the Silures. 
either as a difficulty or as the means of removing difficulties) is that while he makes the entire distance from Isca to Calleva, by Venta Silurum, Abone, Trajectus, Aquæ Solis, Verlucio, Cunetio, and Spinæ, 103 miles, the total of the numbers assigned to the several stages is only 98. As there is absolute certainty as to the identity of Isca with Caerleon, Venta Silurum (the next stage) with Caerwent, and Aquæ Solis with Bath, we have no concern with the stages east of that city, except for the purpose of estimating the probability of the self-evident error of five miles having occurred in one or other portion of the route. Within these reduced limits, the Iter, in the form in which it has reached us, consists of the following stages:--

$$
\begin{aligned}
& \text { AB ISCA -VENTA SILURUM - M.P. IX. } \\
& \text { ABONE - - - IX. } \\
& \text { TRAJECTUS - - IX. } \\
& \text { AQUE SOLIS - . VI. }
\end{aligned}
$$

As the aggregate of the distances assigned to the stages between Venta Silurum and Aquæ Solis is little enough for any of the theories which have been propounded, nearly all who have considered the subject have been glad to make room for the additional length of five miles within that part of the Iter which is the subject of our enquiry. In fact, the distance from Caerwent to Bath, in a straight but impracticable line on the ordnance map, is 23 English, equal to 25 Roman miles, while the aggregate of the three stages given in the uncorrected Iter is only 24 . Some writers have met the difficulty by conjecturing that a station has been altogether omitted ${ }^{1}$-others by changing the Roman numeral $\mathrm{V}$ into an $\mathrm{X}$, or by still more arbi-

${ }^{1}$ In estimating the probability of the various sources of error, the following analysis may be useful. Of the fifteen British Itinera, there are six in which the totals may be considered as exactly agreeing with the added numbers of the stages. I say "may be considered" because in one of them there is a difference of 100 , which so obviously arises from the omission of a $\mathrm{C}$, as to prove nothing except the carelessness of the copyist. These cases shew that the discrepancy cannot have arisen from fractions of a mile, omitted in the stages, having in their aggregate increased the entire distance. In four other cases (of which three arc excesses in the stages, and one in the total) the difference is either one or two miles, which, being too short for a stage, can only have arisen from miscounting the single strokes of Roman numerals. There remain five cases of serious dis. crepancy, four of which, namely differences of 8 miles in 83,19 in 109,9 in 136 , and the present case of 5 in 103 , being excesses in the stated totals over the aggregate of the stages, admit of the possible explanation of an omitted stage, and the remaining case, where the aggregate of the stages exceeds the stated total by 23 in 481, not admitting of that ex. planation, shews the existence of sone other suurce of error. 
trary lengthening of a stage-and others by assuming that the sailing distance across the Estuary has been excluded from the mileage (which, if the object of the Itinerary has been to regulate the marches of soldiers, is possible enough, but ought to affect the total length of the Iter as well as the particular stages), while the names of stations have been made to fit with any theory, by transposing ad libitum the names occurring in Antonine's Iter, as if they had been so many chess-men. Another point of controversy has been the interpretation of the word "Trajectus," some holding it to mean necessarily a ferry crossed as part of the route, or, in the words of Archdeacon Rudge, " an estuary or river broad enough to require the aid of navigation for transport to the other side," in which case it can be no other than the Severn ; and others regarding it merely as a local name, indicating the site or neighbourhood of a ferry, either on the route or diverging from it.

The theory I have to propose is that the name "Trajectus" has occurred twice in this portion of the Iter, in a sense wide enough to admit of either construction. We may then either assign to the omitted stage the missing length of five miles (the omission of a single line, "Trajectus V," being a mistake which it is only too easy to commit or to account for), or may read the text thus-

\begin{tabular}{|c|c|c|c|}
\hline AB ISCA-VENTA SILURUM & & & M.P. IX \\
\hline TRAJECTUS & 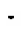 & & IX \\
\hline ABONE - & - & - & \\
\hline TRAJECTUS & - & . & IX \\
\hline AQU.E $\mathbb{E}^{1}$ SOLIS & - & - & VI \\
\hline
\end{tabular}

Even if the text has originally stood as last above suggested, the mental process leading to the mistake is not difficult to imagine; and a mistake is never so satisfactorily corrected as when it can be shown how it has arisen. The copyist, having written the first line correctly, "Ab Isca-Venta Silurum-M.P. IX," and being on the point of writing "Trajectus" in the second line, takes the precaution, as a nervous writer is apt to do, of a second

1 I write the name in the nominative, instead of the "Aquis Solis" of the original, not by way of emendation, but for uniformity. In fact the ablative of that and other names, in company with the nominative of Trajectus, raises another question, not necessary for me to discuss, whether Abone is a nominative or the ablative of some such word as Abo or Abon. 
glance at the original, and his eye falls on the second "Trajectus" instead of the first. Not noticing that the name occurs twice, and seeing "Abone" above it, he imagines that he has been just in time to save himself from a mistake, and writes "Abone" in the second line. For the number he looks only at the column of figures, and seeing "IX" as the second number, he writes it upposite to "Abone," and the mistake is complete. The first "Trajectus" being thus quietly consigned to oblivion, the unconscious scribe proceeds with the second "Trajectus" for his third line, in the form in which it has come down to the present day.

If the text be thus restored, Trajectus (1) is of course a station at or near the head of the ferry over the Severn, while Trajectus (2), so far as this theory is concerned, may be placed at Bitton, Keynsham, or Hanham, each of which has had its advocates. On this and the other questions involved in fixing the precise route, and assigning the position of the stations, I have not sufficient local knowledge of the country east of the Severn to speak authoritatively, and my object is not to advocate any route of my own selection, but to shew how my suggestion removes some of the principal difficulties attending the theories of previous enquirers. Among the earlier ones Oldbury was long the favourite site for Trajectus, being also the point to which they brought roads from Corinium, or Durocornovium (Cirencester), and Glevum, crossing the Severn on the way to Venta Silurum. Mr. Ormerod, whose remarks are entitled to the more weight as they were printed before the discovery of Roman remains on his estate at Sedbury, supported the theory of there having been in this direction at least a British road of Roman adoption, by adducing the modern use of a passage, "described by Seyer as being of the remotest antiquity," from Oldbury Pill to Sedbury, on the promontory between the Severn and the Wye, and thence to a passage over the latter river, ${ }^{1}$ beneath the camp on Hardwick Cliffs, a little below Chepstow, which he connected

$1 A$ road across the promontory in this direction having much the appearnnce of a British trackway is marked in the Ordnance map as a Roman road; but its character has been too much altered by earthworks thrown up during the Civil War (to say nothing of Mr. Ormerod's identification of a portion of it as Offa's Dyke) to furnish satisfactory evidence. 
with traces of the Roman road in the direction of Caerwent (Strigulensia, pp. 6, 7, 21). From Oldbury the five mile stage which our new reading gives us will take us to Almondsbury, on the Ridgeway, or to Knowle Camp, in its immediate neighbourhood, as the site of Abone. IIorsley objects that Oldbury is too far to the north; and Mr. Ormerod, notwithstanding the passage above noticed, appears to concur in the objection (Strig. p. 33). If Oldbury be rejected on this ground, Aust Cliff; the Trajectus Augusti of Lysons, though nearer in a straight line to Almondsbury or Knowle, is in fact about the same distance allowing for the detour by Elberton, rendered necessary by the nature of the ground, the entire tract between the Severn and the line of places shewn on the map being, in Roman times, an impracticable marsh. The derivation of the name of the Aust Passage from the Legio Secunda Augusta, so long stationed at Isca Silurum, has been too summarily dismissed by Mr. Ormerod (Strig., p. 22) on the ground that " the designation of this place as Austreclive in Domesday seems only to point to its position with respect to the Severn :" and he discusses in a note the question what point of the compass is indicated by "Austre." Tho orthography of local names was not the strong point of the compilers of Domesday. At all events they were not archæologists ; and not professing to carry their researches further back than the "tempus Regis Edwardi" they might well be excused for writing the name, after an interval of more than six hundred years from the departure of the Romans from Britain, in a form which conveyed some meaning to their own ears, without enquiring into its origin; and the probable derivation of the name is entitled to its due weight in connecting the Aust Passage with the Roman Iter: The reading of Trajectus (1) as meaning Aust Cliff is consistent either with the route of Antonine being by what until a very few years ago was in use as the "Old Passage" to the Beachley promontory, or with Horsley's view of a passage direct to Aust from Sudbrook, subject only to the objections which shall be presently noticed. Our five mile stage will then take us to Almondsbury, or Aunsbury, which Horsley makes the site of Abone, without 
the difficulty incident to his making it a nine mile stage fiom Venta Silurum, which is less than the actual distance "as the crow flies;" and we have a reason for the short stage in the fact that it formed a junction with a previously existing route from south-west to north-east along the Ridgeway.' From Almondsbury or Knowle Camp, Mr. Ormerod's improvement on Seyer's route (Strig. p. 32) presents no difficulty. He would take it direct to St. George's, from which point to Bitton and Bath the road can be traced by existing remains. But whether Bitton, Keynsham, or Hanham be preferred as the site of Trajectus (2), it is satisfactory to be able to adopt it without being exposed to the weighty objection that it is impossible to suppose the ferry over the Severn to have been unnoticed while mention was made of that over the Avon or the Boyd; and, on the other hand, to be able to bring Trajectus to the Severn without having recourse to Roger Gale's bold expedient of "castling," which, in spite of the approval of it by subsequent antiquaries in despair of a better solution, is at best only the assumption of one error in the Itinerary without correcting another.

The objection to the routes by Sudbrook or Beachley to Aust is that by neither line of communication can the distance from Venta Silurum to Aust Cliff be made more than about seven miles, whereas the Iter requires nine. If the route by Sudbrook be preferred, an observation of Horsley (Brit. Rom., p. 470) suggests a way out of the difficulty. He says "It is by no means necessary to suppose that the station next to the passage should be near or close to the river, for this does not hold true in any one instance either on the Severn or Humber, where, the water being too broad for a bridge, a ferry has been made use of." If this be so we may still adopt the Aust Passage, and place Trajectus (1) further inland, at Elberton, the site of an undisputed Roman camp (Strig. p. 22.) The five mile stage would then form a junction with the more ancient road at or north of Almondsbury, and thence by Cribbs Causeway, to Henbury, the Abone

\footnotetext{
1 There is no other instance in the Itinera of so short it stage as five miles. There are two cases of sis, including
} are of frequent occurrence. 
of Stukeley; and the next stage of nine miles, diverging at that point from the road to Sea-Mills, would reach Bitton by St. George's.

The route by Beachley is subject to the further diffculty that it makes no provision for the crossing of the Wye, which, at the point of the traditional passage under Hardwick Cliffs, is a deep and rapid river, the fording of which is out of the question. Mr. Ormerod, however, has pointed out, in a paper in the Archooologice (vol. xxix), reprinted in his Strigulensia (see pp. 8, 39), that a vicinal road from Glevum to Venta Silurum crossed the Wye under Piercefield woods, about half a mile above the present Chepstow bridge, at a point where there is a tradition of an ancient bridge, where remains of stakes and of a pier are still visible at very low tides, and where the road, ascending the face of Piercefield Cliffs by an incline of evidently artificial formation, is very apparent. Now if this was the best crossing of the Wye, it would account for a little detour, and would bring the distance from Caerwent, by Beachley, to Aust to about the nine miles of the Itinerary, and enable us, as before suggested, to place Abone at Almondsbury. It is possible indeed (I abstain from saying probable, but offer it as a new theory to the choice of future enquirers) that this very crossing above Chepstow may be the Trajectus of which we are in search, indicating the commencement of the passage over both the Wye and the Severn, instead of a point beyond both rivers, and that the mistake in the Iter has been the omission of "Trajectus V" between Venta Silurum and Abone, without any alteration of the figures attached to those places. The next stage of nine miles would then take us, by Beachley and Aust, to Almondsbury, and the Iter would read thus :-

AB ISCA-VENTA SILURUM
TRAJECTUS
ABONE -
TRAJECTUS :
AQUA SOLIS :

$\begin{array}{rr}- & \text { M.P. IX. } \\ : & \text { V. } \\ : & \text { IX. } \\ : & \text { VI. }\end{array}$

The actual distances I have mentioned, and the scale attached to the map are in English miles. I must leave those who expect from the Iter measured Roman miles, and not estimated distances, to adjust the discrepancy; but it is not of serious amount, as the Itinerary in no case 
purports to give fractions of a mile, and the difference would not amount to an entire mile in the longest stage we have had to deal with. As the map is intended only to make my observations intelligible, I have not thought fit to assert or seem to assert an opinion by giving any Roman names, except those which are beyond dispute, or by marking connecting lines between any of the places, my aim and intention being, as I beg to repeat, to suggest such new reading of the text as, independent of its bearing on any favourite theory, may furnish a light by which the extensive literature on the subject may be read afresh, and the better information of others may enable them to identify the various stations with more authority than I can pretend to exercise. 